\title{
Helicobacter pylori vacA s $1 m 1$ genotype but not cagA or babA2 increase the risk of ulcer and gastric cancer in patients from Southern Mexico
}

\author{
Adolfo Román-Román', Dinorah Nashely Martínez-Carrillo², Josefina Atrisco-Morales², \\ Julio César Azúcar-Heziquio², Abner Saúl Cuevas-Caballero², Carlos Alberto Castañón-Sánchez³, \\ Roxana Reyes-Ríos ${ }^{2}$, Reyes Betancourt-Linares ${ }^{4}$, Salomón Reyes-Navarrete ${ }^{5}$, Iván Cruz-del Carmen ${ }^{6}$, \\ Margarita Camorlinga-Ponce ${ }^{7}$, Enoc Mariano Cortés-Malagón ${ }^{8}$ and Gloria Fernández-Tilapa ${ }^{2 *}$ (i)
}

\begin{abstract}
Background: The vacA, cagA and babA2 genotypes of Helicobacter pylori are associated with gastric pathology. The objectives were to determine the frequency of infection and distribution of the $v a c A$, cagA and babA2 genotypes of H. pylori in patients with gastric ulcer, chronic gastritis and gastric cancer, and to evaluate the association of virulent genotypes with diagnosis.

Methods: We studied 921 patients with symptoms of dyspepsia or with presumptive diagnosis of gastric cancer. The DNA of H. pylori and the vacA, cagA and babA2 genes was detected by PCR in total DNA from gastric biopsies. The association of $H$. pylori and of its cagA, vacA and babA2 genotypes with diagnosis was determined by calculating the odds ratio $(\mathrm{OR})$.

Results: Chronic gastritis was confirmed in 767 patients, gastric ulcer in 115 and cancer in 39. The prevalence of $H$. pylori was $47.8,49.6$ and $61.5 \%$ in those groups, respectively. H. pylori was more frequent in the surrounding tissue (69.2\%) than in the tumor (53.8\%). The vacA $1 \mathrm{~m} 1$ genotype predominated in the three groups $(45.2,61.4$ and $83.3 \%$, respectively). H. pylori was associated with cancer $\left(\mathrm{OR}_{\text {adjusted }}=2.08 ; 95 \% \mathrm{Cl} 1.05-4.13 ; p=0.035\right)$ but not with ulcer $\left(\mathrm{OR}_{\text {adjusted }}=1.07 ; 95 \% \mathrm{Cl} 0.71-1.61 ; p=0.728\right)$. The $51 \mathrm{~m} 1$ genotype was associated with ulcer and cancer $\left(\mathrm{OR}_{\text {adjusted }}=2.02 ; 95 \% \mathrm{Cl} 1.12-3.62 ; p=0.019\right.$ and $\mathrm{OR}_{\text {adjusted }}=6.58 ; 95 \% \mathrm{Cl} 2.15-20.08 ; p=0.001$, respectively $)$. babA2 was associated with gastric cancer, and cagA was not associated with the diagnosis.
\end{abstract}

Conclusions: In population from Southern Mexico, H. pylori and the $51 \mathrm{~m} 1$ genotype were associated with gastric cancer and the $51 \mathrm{~m} 1 / \mathrm{cag} A+/ b a b A 2+$ strains predominated in tumor and adjacent tissue.

Keywords: H. pylori, Chronic gastritis, Gastric ulcer, Gastric cancer, vacA, cagA, babA2

\section{Background}

Persistent infection with Helicobacter pylori (H. pylori) induces chronic inflammation, tissue damage,

\section{*Correspondence: gferti@hotmail.com}

${ }^{2}$ Laboratorio de Investigación Clínica, Facultad de Ciencias Químico Biológicas, Universidad Autónoma de Guerrero, Avenida Lázaro Cárdenas S/N Ciudad Universitaria Sur, Col. La Haciendita, 39087 Chilpancingo, Guerrero, México

Full list of author information is available at the end of the article deregulation of cellular regeneration and gastric carcinogenesis. The adhesion of $H$. pylori to epithelial cells of the gastric mucosa induces a marked inflammatory response, leading to chronic gastritis, peptic ulcer disease and gastric cancer $[1,2] . H$. pylori colonize the gastric mucosa of up to 70 to $80 \%$ of the adults living in developing regions such as Africa and Latin America [3, 4]. In Mexico, the seroprevalence of $H$. pylori is 58 to $66.7 \%$ in 
people without symptoms of dyspepsia [5-8]; in patients with gastroduodenal pathology, the frequency of infection ranges from 60.1 to $87.4 \%$ [6,9-12], a higher prevalence than that in some Southeast Asian countries [4]. However, not all carriers develop severe gastrointestinal diseases with clinical symptoms. Gastroduodenal diseases result from the interaction between genotypes of $H$. pylori and host and environment factors $[13,14]$.

The genomes of $H$. pylori are heterogeneous and encode different virulence factors that play an important role in the clinical outcome of the infection [1]. The proteins encoded by the $\operatorname{cag} A, v a c A$ and $b a b A 2$ genes determine the pathogenicity of $H$. pylori and have been well described [15].

The babA2 gene encodes the blood group antigenbinding adhesin (BabA), which binds to the fucosylated Lewis $b$ antigen present on the surface of gastric epithelial cells. BabA facilitates colonization, persistence of infection and release of virulence factors of the bacterium. Infection with babA2-positive $H$. pylori has been associated with gastric ulcer, duodenal ulcer and gastric adenocarcinoma and is related to increased risk of severe disease when it coexists with the $\operatorname{cag} A$ gene and the $v a c A s 1$ allele. Although three $b a b$ alleles have been identified ( $b a b A 1, b a b A 2, b a b B)$, only the product of the $b a b A 2$ gene is required for the binding of $H$. pylori to Lewis $\mathrm{b}$. The association of BabA2 with severe gastric disease is controversial, but it is known that the interaction between BabA2 and Le $\mathrm{e}^{\mathrm{b}}$ activates the production of pro-inflammatory cytokines (CCL5, IL-8) and other molecules related to precancerous lesions (CDX2, MUC2) $[1,2,15-18]$. The frequency of babA2-positive H. pylori ranges from 21.7 to $82.3 \%$ in Latin American countries $[10,19,20]$.

The cytotoxin-associated gene A (CagA) is a protein of 125-145 kDa encoded by the cagA gene, and an important virulence factor of $H$. pylori. The cagA gene is part of a genetic locus of $40 \mathrm{~kb}$ called cag pathogenicity island (cag-PAI) consisting of 27-31 genes, including those that encode a type IV secretion system (T4SS) that is responsible for the translocation of CagA to the cytoplasm of gastric epithelial cells by cagA-positive strains of $H$. pylori [21-23]. The cagA gene is a marker for the presence of cag-PAI; however, not all strains expressing the CagA protein genes express all cag-PAI genes. Based on the presence of $\operatorname{cagA}$, the strains of $H$. pylori are grouped into cagA-positives and cagA-negatives. The prevalence of gastric diseases associated with $H$. pylori is higher among patients infected with cagA-positive strains. CagA is translocated into epithelial cells and activates signaling pathways that induce cellular changes and the production of IL-8 and other proinflammatory cytokines. The proinflammatory potential of cagA-positive $H$. pylori may explain its association with severe atrophic gastritis, peptic ulcer and gastric adenocarcinoma [24-26]. The frequency of cagA-positive $H$. pylori is $90-95 \%$ in Asian countries and $50-60 \%$ in Western countries. In Mexico, the prevalence of cagA varies from 47.6 to $63.4 \%$, and the prevalence of anti-CagA+ antibodies among patients with gastric diseases reaches to $70.9 \%[12,27]$. The distribution of $\operatorname{cagA} A$-positive strains varies between regions and ethnic groups [28-30].

The vacuolating cytotoxin A (VacA) of H. pylori is associated with the risk of developing gastric cancer. VacA is encoded by the vacA gene, present in all strains of $H$. pylori. The $v a c A$ gene has a variable structure in the signal region $(s)$, with $s 1$ or $s 2$ allele types; the intermediate region $(i)$ exists as subtypes 1 and 2 , while the middle region $(m)$ has $m 1$ and $m 2$ allele types. The combination of allele types from each region results in the structure of the $v a c A$ gene, which determines the levels of toxin production. The vacA $s 1 / \mathrm{m} 1$ strains of $H$. pylori produce high levels of cytotoxin; the $s 1 / \mathrm{m} 2$ strains produce moderate levels, while the $s 2 / m 2$ strains produce minimal concentrations or do not produce it at all [31,32]. The $\operatorname{sim} 1$ and $s 1 m 2$ genotypes generate VacA isoforms that cause direct damage to the gastric epithelium and stimulate an acute inflammatory process, which may lead to chronic gastritis or gastric ulcer [33-37]. The prevalence of the genotypes of $H$. pylori that express the most virulent factors changes with the geographic area [15], and the prevalence of infection with $H$. pylori vacA $\operatorname{sim} 1$ correlates with increased risk of disease [38].

The incidence of gastritis, ulcers and duodenitis has increased in the Mexican population in the last 10 years [39]. It is recognized that up to $80 \%$ of functional dyspepsia, $85-90 \%$ of peptic ulcers and $90 \%$ of gastric cancers are associated with infection by $\mathrm{H}$. pylori [40]. The incidence rate of gastric cancer in Mexican men and women is 7.9 and 6.0/100,000, respectively [41]. However, despite the increase in the number of cases associated with $H$. pylori, there are few data on the prevalence of this infection in some gastroduodenal diseases, and still fewer on the distribution of the $v a c A, \operatorname{cag} A$ or $v a c A / \operatorname{cag} A$ genotypes in patients with peptic ulcers, non-ulcer dyspepsia or gastric cancer $[6,10,11,27,42-45]$, while there is only one study on the frequency of the vacA, cagA and babA2 genotypes in patients with chronic gastritis [10]. There are no studies on the prevalence of $H$. pylori, the distribution of the $v a c A$, cagA and $b a b A 2$ genotypes and, simultaneously, on the relationship of these genes with clinical outcome in Southern Mexico population. The objective of this research was to determine the frequency of gastric infection and the distribution of the $v a c A, \operatorname{cag} A$ and babA2 genotypes of $H$. pylori in patients with gastric ulcer (GU), chronic gastritis (CG) and gastric 
cancer (GC). We also evaluated the association of these virulent genotypes with clinical outcome. This information will reveal the distribution of genotypes of $H$. pylori in Southern Mexico and may be useful for understanding the clinical relevance of genotyping in order to predict the clinical outcome of infection and to define therapeutic and prevention strategies for gastroduodenal diseases related to infection.

\section{Methods}

\section{Patients}

We studied 921 patients who were consecutively selected from those suffering from dyspepsia symptoms or who had presumptive diagnosis of gastric cancer. Eight hundred and eighty-two underwent upper endoscopy in the General Hospital Dr. Raymundo Abarca Alarcón or in the Specialized Unit for Gastroenterology Endoscopy in Chilpancingo; 39 underwent endoscopy for suspected gastric cancer in the State Institute of Oncology in Acapulco, Guerrero, Mexico. We included patients without antimicrobial treatment and without intake of proton pump inhibitors or of gastric $\mathrm{pH}$ neutralizers during the month prior to endoscopic procedure. Patients with immunosuppressant or nonsteroidal anti-inflammatory treatment were excluded from the study. The patients or their parents signed statements of informed consent. The patients were selected between March 2006 and May 2014. The project was approved by the Bioethics Committee of the Universidad Autónoma of Guerrero, by the Research Department of the State Cancer Institute and by the Department of Teaching and Research of the General Hospital Dr. Raymundo Abarca Alarcón.

\section{Endoscopy and histology}

The endoscopy was performed after an overnight fast with a video processor and video gastroscope (Fujinon, Wayne, NJ USA). In patients with GC and GU, two biopsies were taken from the antrum, body or ulcer edge. In patients with $\mathrm{GC}$, two biopsies were taken from the tumor and two from tissue adjacent to the cancer. A biopsy of each site was fixed immediately in formalin (10\%) for histological examination and another was placed in a buffer solution $(10 \mathrm{mM}$ Tris $\mathrm{pH} 8.0,20 \mathrm{mM}$ EDTA pH 8.0, 0.5\% SDS) for diagnosis of $H$. pylori. The biopsies intended for $H$. pylori detection were kept at $-20{ }^{\circ} \mathrm{C}$ until processing. The biopsies fixed in formalin were embedded in paraffin. Tissue sections of $4 \mu \mathrm{m}$ were stained with hematoxylin-eosin for histological study. The histopathological diagnosis was made according to the updated Sydney system [46], or based on the International Padova Classification of gastric dysplasia [47]. The endoscopic and histopathological findings were used only for diagnosis.

\section{Detection of $H$. pylori and genotyping of vacA}

The total DNA from gastric biopsies and bacterial packets was extracted by the phenol-chloroform-isoamyl alcohol technique after proteinase $\mathrm{K}$ digestion [48]. The DNA of $H$. pylori was detected with conventional PCR using oligonucleotides directed to the $16 S$ rRNA gene [37]. PCR specificity was tested with DNA from different bacteria no $H$. pylori, isolated from gastric biopsies from the same patients. It was also tested with DNA from Campylobacter sp., a bacterium phylogenetically related to $H$. pylori (Fig. 1a). DNA integrity was verified adding a set of primers specific for $I L-1 B$ gene in the PCR for $H$. pylori $16 S$ rRNA gene. $I L-1 B$ primers sequences were sense $5^{\prime}$-CAT TTG TCA GGT TCT TGA TC- $3^{\prime}$ and antisense $5^{\prime}$-GAA GTT TAG TCT TCC CAC TT- $3^{\prime}$ which amplified a 305 bp fragment (Fig. $3 \mathrm{a}-\mathrm{C}$ ). We only included in the study the samples $I L-1 B$-positive. GC patients were considered $H$. pylori-positive when the $16 \mathrm{~S}$ $r R N A$ gene was detected in the tumor, in the adjacent tissue, or both. The signal and middle regions of $v a c A$ were genotyped by PCR using the oligonucleotides previously used by Atherton et al., and Park et al, and according to the methodology described by Martínez-Carrillo et al, $[6,35,49]$. To ensure that we did genotyped correctly vacA alleles we tested by PCR a DNA sample from a $H$. pylori positive biopsy and DNA from a clinical strain of H. pylori that we isolated from a patient with chronic gastritis. We classified as genotype $s 1 m 1$ or $s 2 m 2$ by comparison with the amplicons obtained from strains ATCC43504 with genotype s1m1 and 8822 (TX30) vacA $s 2 m 2$ of H. pylori (Fig. 1b, c).

\section{Detection of cagA}

The positive samples for the $16 S$ rRNA gene of $H$. pylori were subjected to PCR for detection of cagA using the oligonucleotides cagAF 5'-ACAATGCTAAATT AGACAACTTGAGCGA- $3^{\prime}$ and cagAR $5^{\prime}$ TTA GAATAATCAACAAACATCACGCCAT-3' [50], which amplified a $297 \mathrm{bp}$ fragment of the constant region; the set cag2F5'-GGAACCCTAGTCGGTAATG-3' and cag4R $5^{\prime}$-ATCTTTGAGCTTGTCTATCG-3' $[51,52]$ was used to amplify $500-850$ bp of the $3^{\prime}$ variable region of cagA. The reaction mixture was prepared with $1.7 \mathrm{mM} \mathrm{MgCl}_{2}$, $0.2 \mathrm{mM}$ dNTPs (Invitrogen, Carlsbad, CA, USA), $5 \mathrm{pmol}$ of each oligonucleotide, $1 \mathrm{U}$ of Taq DNA polymerase Platinum (Invitrogen, Carlsbad, CA, USA) and $300 \mathrm{ng}$ of total DNA in a volume of $25 \mu \mathrm{L}$. The amplification program included one cycle at $94{ }^{\circ} \mathrm{C}$ for $5 \mathrm{~min}, 30$ cycles at $94{ }^{\circ} \mathrm{C}$ for $40 \mathrm{~s}, 56{ }^{\circ} \mathrm{C}$ for $30 \mathrm{~s}$ and $72{ }^{\circ} \mathrm{C}$ for $50 \mathrm{~s}$, and a final extension cycle at $72{ }^{\circ} \mathrm{C}$ for $10 \mathrm{~min}$. The PCR products were subjected to electrophoresis on agarose gel (1.5\%), the gels were stained with ethidium bromide and observed under ultraviolet light (UV). The samples were 


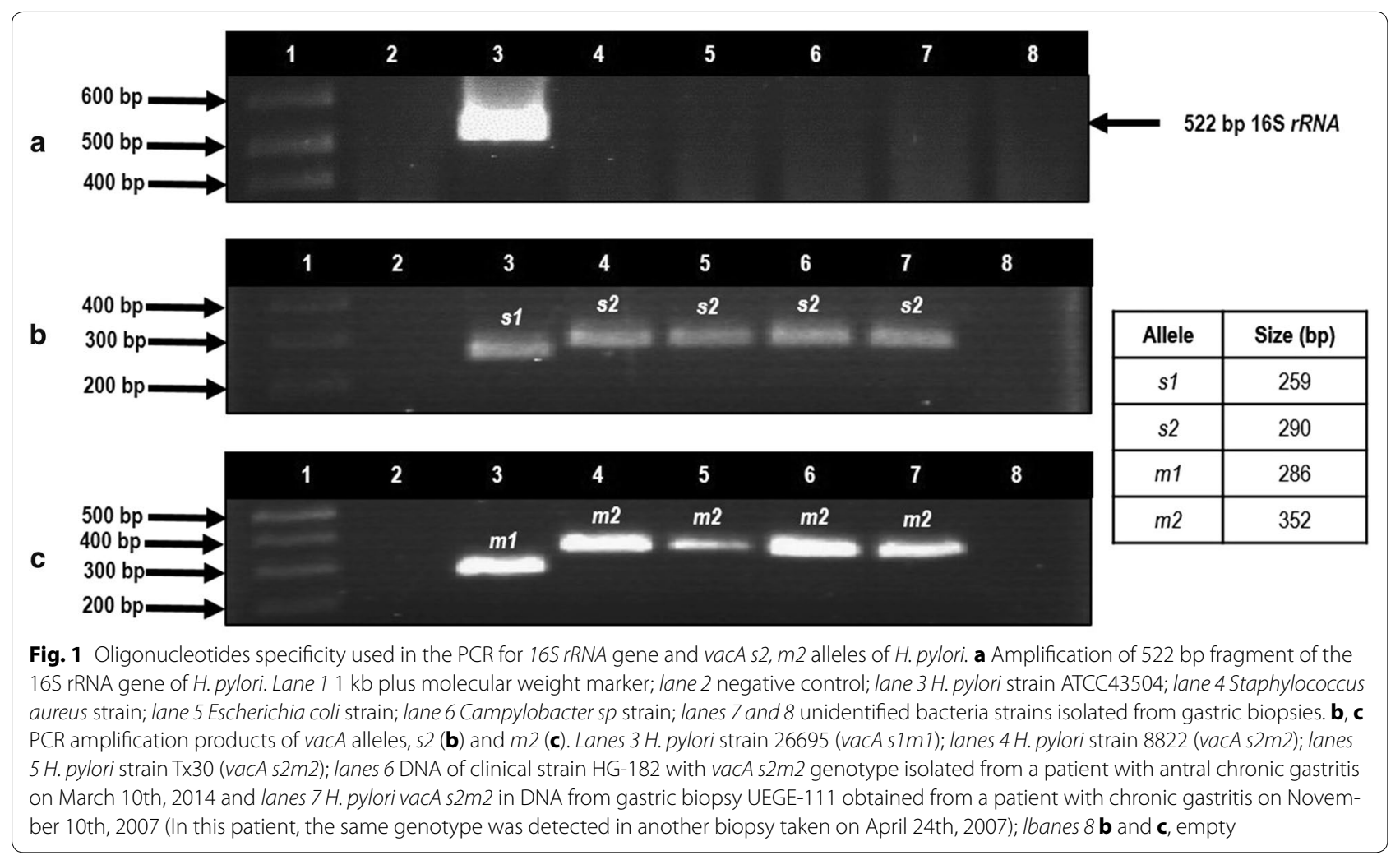

considered cagA-positive when at least one of the two bands was observed.

\section{Detection of $b a b A 2$}

The presence of $b a b A 2$ was verified by mismatch PCR using the following oligonucleotides: F5'AATCCAAAAAGGAGAAAAAACATGAAA- $3^{\prime}$ and R5'-TGTTAGTGATTTCGGTGTAGGACA-3', designed by Gerhard et al. [16], (Fig. 2). The amplification reaction was performed in a final volume of $15 \mu \mathrm{L}$, with $3.0 \mathrm{mM}$ $\mathrm{MgCl}_{2}, 0.25 \mathrm{mM}$ dNTPs, 5 pmol of each oligonucleotide, $1 \mathrm{U}$ of Taq DNA polymerase Platinum (Invitrogen, Carlsbad, CA, USA) and 600 ng of total DNA. The amplification program included an initial denaturation cycle at $95{ }^{\circ} \mathrm{C}$ for $3 \mathrm{~min}, 40$ cycles at $95{ }^{\circ} \mathrm{C}$ for $30 \mathrm{~s}, 57{ }^{\circ} \mathrm{C}$ for $40 \mathrm{~s}, 72{ }^{\circ} \mathrm{C}$ for $45 \mathrm{~s}$, and a final extension cycle at $72{ }^{\circ} \mathrm{C}$ for $5 \mathrm{~min}$. The PCR products were subjected to electrophoresis on agarose gel (1.0\%); the gels were stained with ethidium bromide and visualized under ultraviolet light (UV). The samples were considered babA2-positive when a band of 850 bp was observed.

DNA from the ATCC 43504 strain of $H$. pylori (vacA $s 1 \mathrm{~m} 1 / \operatorname{cag} A+/ b a b A 2+)$ was used as positive control in all PCR reactions; template DNA was substituted by sterile deionized water as negative control. DNA from a gastric biopsy was used as positive control for $s 2$ and $m 2$ allele types. All the PCR reactions were performed in a Mastercycler Ep gradient thermal cycler (Eppendorf, Germany).

\section{Statistical analysis}

We used $\mathrm{X}^{2}$ or Fisher's exact test to compare frequencies between groups, and analysis of variance (ANOVA) to compare means. The association of $H$. pylori and the $\operatorname{cag} A, v a c A$ and $b a b A 2$ genotypes with the clinical outcome was determined by multinomial logistic regression models. A $p$ value $<0.05$ was considered statistically significant. All statistics were calculated with Stata V.9.2 (College Station, Texas, USA).

\section{Results}

Patients and histological diagnosis

Of the 921 patients enrolled in the study, 83.3\% had chronic gastritis, $12.5 \%$ had gastric ulcer and $4.2 \%$ had gastric cancer. The average age was $47.3 \pm 16.2$ years for cases of chronic gastritis (range 6-91 years); $54.9 \pm 17.5$ years for patients with gastric ulcer (range 9-90 years) and $59.2 \pm 18.4$ years for patients with gastric cancer (range 27-87 years). In chronic gastritis and gastric ulcer patients, the most frequent age group was $40-59$ years ( $45.8 \%$ and $40.9 \%$, respectively) and in the group of gastric cancer, $53 \%$ of patients were $\geq 60$ years. Women predominated in all groups. The groups were 


\author{
A A T C C A A A A A G G A G A A A A A A C A T G A A A A A A C A C A T C \\ $\begin{array}{lllllllllllllllllllllllllll}\text { I } & \text { I } & \text { I } & \text { I } & \text { I } & \text { I } & \text { I } & \text { I } & \text { I } & \text { I } & \text { I } & \text { I } & \text { I } & \text { I } & \text { I } & \text { I } & \text { I } & \text { I } & \text { I } & \text { I } & \text { I } & \text { I } & \text { I } & \text { I } & \text { I } & \text { I } & \text { I }\end{array}$ \\ 5'-A A T C C A A A A A G G A G A A A A A A C A $T$ G A A A
}

babAl GenBank: AF001388.1

\title{
A A T C C A A A A A G G A G A A A A A A C A C A

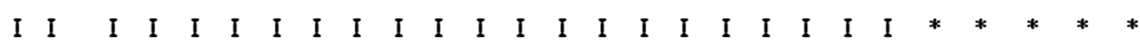

5'-A A T C C A A A A A G G A G A A A A A A C A T G A A A-3'

Fig. 2 Forward primer binding to babA2 and babA1 gene sequences. Detection of bab2A gene is determined by perfect match of $3^{\prime}$ - end from forward primer. Differences between babA2 and bab1 sequences are shown in the increased font size and matches are indicated by vertical bars; mismatches are indicated by asterisks. babA1 and babA2 have almost complete sequence homology, with the exception of an approximately 10 bp insert, found only in $b a b A 2$, which creates a translational initiation codon in the signal peptide sequence. Gerhard et al. used this sequence difference to amplify the babA2 gene selectively by mismatch PCR [16]

significantly different in age $(p<0.001$, ANOVA test), level of education and in living in overcrowded housing $(p<0.05)$ (Table 1$)$.

\section{Prevalence of $\boldsymbol{H}$. pylori}

The prevalence of $H$. pylori was 48.6\% (448/921) (Fig. 3ac), and the frequency of infection increased with disease severity (Table 2). H. pylori was more prevalent in patients with chronic gastritis and gastric ulcer in the range of 40-59 years ( 44.1 and $45.6 \%$, respectively), but in gastric cancer, the highest frequency of $H$. pylori-positive patients $(50 \%)$ were $\geq 60$ years of age. Seventy-five percent (12/16) of patients younger than 20 years of age with chronic gastritis harbored $H$. pylori cagA+ in combination with different $v a c A$ genotypes. Seven of these patients were children aged 11-16 years old. A 19-year old patient with gastric ulcer was infected with a $v a c A$ $s 1 m 1 / c a g A+/ b a b A 2+$ strain. The presence of $H$. pylori was investigated in DNA from tissue adjacent to cancer and from tumor in 13 of the 39 patients with gastric cancer; $53.8 \%(7 / 13)$ were $H$. pylori-positive in both sites and in $15.4 \%(2 / 13)$ the $16 S$ rRNA gene was detected in tissue adjacent to cancer but not in the tumor. The prevalence of $H$. pylori was not significantly different between groups $(p=0.243)$ (Table 2$)$.

\section{vacA genotypes}

The $v a c A \operatorname{sim} 1$ genotype was the most frequent among $H$. pylori-positive patients, with $54.5 \%$ (244/448) (Fig. 3d). In $49.3 \%(221 / 448)$ of these patients, only the $s 1 \mathrm{~m} 1$ allele types were detected, while $s 1 \mathrm{~m} 1$ was found in co-infection with $s 1 \mathrm{~m} 2$ in $5.1 \%$ of patients $(23 / 448)$. In $5.4 \%(24 / 448)$ of patients, the $s 1$ allele was detected but the $m$ region was undetectable $(s 1 m 0)$; on the other hand, the $m 2$ allele was identified in 4 patients but the $s$ region could not be identified ( $s 0 m 2$ ) (Table 2). vacA $s 1 m 2$ was found in $15.4 \%$ of samples $(69 / 448)$. The same allele combinations of $v a c A$ were found in tissue adjacent to cancer and in tumor: $38.5 \%(5 / 13) s 1 m 1$ and $15.4 \%(2 / 13) s 2 m 2$ (Fig. 3d) (Table 3). It was impossible to genotype the $v a c A$ gene in $42(9.4 \%)$ of the $448 \mathrm{H}$. pylori-positive patients. The prevalence of $v a c A$ genotypes and alleles varied with clinical outcome; $v a c A s 1 m 1$ was the most frequent in all groups. Significant differences were found in the distribution of $v a c A$ genotypes between groups $(p=0.017)$ (Table 2).

\section{Frequency of cagA and babA2}

Four hundred and twelve of the $448 \mathrm{H}$. pylori-positive biopsies were tested for $\operatorname{cag} A$ (Fig. 3e). The cagA gene was detected in $62.6 \%(258 / 412)$ of patients studied; the frequency was similar among infected patients in the three groups. No significant differences were found in the frequency of $H$. pylori-cagA+ between groups $(p=0.925)$ (Table 2). In cancer, $71.4 \%$ (5/7) of tumor and surrounding tissue biopsies positive for $H$. pylori in both sites harbored $\operatorname{cag} A+$ strains.

A total of 423 DNA samples were analyzed for babA2 (Fig. 3f). The babA2 gene was detected in $29.3 \%$ (124/423) of $H$. pylori-positive patients. babA2 was found in patients from all groups but it was more frequent in gastric cancer; however, there were no significant differences in the frequency of $H$. pylori-babA2+ strains between groups $(p=0.114)$ (Table 2$)$. Fifty-nine point seven percent $(74 / 124)$ of the samples positive for babA2+ had also $v a c A s 1 m 1 / c a g A+$. Seventy-one point 4 
Table 1 Sociodemographic characteristics of 921 Mexican patients with chronic gastritis, gastric ulcer and gastric cancer

\begin{tabular}{|c|c|c|c|c|}
\hline & \multicolumn{4}{|l|}{ Diagnosis } \\
\hline & $\begin{array}{l}C G n=767 \\
n(\%)\end{array}$ & $\begin{array}{l}\mathrm{GU} n=115 \\
\mathrm{n}(\%)\end{array}$ & $\begin{array}{l}\mathrm{GC} n=39 \\
\mathrm{n}(\%)\end{array}$ & $p$ value \\
\hline \multicolumn{5}{|l|}{ Age (years) } \\
\hline$\leq 20$ years old & $32(4.2)$ & $3(2.6)$ & 0 & \multirow[t]{4}{*}{$<0.001^{\delta}$} \\
\hline 20-39 years old & $218(28.4)$ & $20(17.4)$ & $9(23.1)$ & \\
\hline 40-59 years old & $348(45.4)$ & $48(41.7)$ & $9(23.1)$ & \\
\hline$\geq 60$ years old & $169(22)$ & $44(38.3)$ & $21(53.8)$ & \\
\hline \multicolumn{5}{|l|}{ Gender n (\%) } \\
\hline Female & $471(61.4)$ & $65(56.5)$ & $24(61.5)$ & \multirow[t]{2}{*}{$0.603^{\Phi}$} \\
\hline Male & $296(38.6)$ & $50(43.5)$ & $15(38.5)$ & \\
\hline \multicolumn{5}{|l|}{ Education n (\%) } \\
\hline College or higher & 367 (47.9) & $43(37.4)$ & $3(7.7)$ & \multirow[t]{5}{*}{$<0.001^{\delta}$} \\
\hline High school & $114(14.9)$ & $16(13.9)$ & $5(12.8)$ & \\
\hline Junior high school & $90(11.7)$ & $5(4.4)$ & $4(10.3)$ & \\
\hline Elementary school & $143(18.6)$ & $31(26.9)$ & $15(38.5)$ & \\
\hline Uneducated & $53(6.9)$ & $20(17.4)$ & $12(30.7)$ & \\
\hline \multicolumn{5}{|l|}{ Smoking habit n (\%) } \\
\hline No & $441(57.5)$ & $53(46.1)$ & $20(51.3)$ & \multirow[t]{2}{*}{$0.060^{\Phi}$} \\
\hline $\begin{array}{l}\text { Current or previ- } \\
\text { ous smoker }\end{array}$ & $326(42.5)$ & $62(53.9)$ & $19(48.7)$ & \\
\hline \multicolumn{5}{|l|}{ Alcohol drinking n (\%) } \\
\hline No & $185(24.1)$ & $37(32.2)$ & $9(23.1)$ & \multirow[t]{2}{*}{$0.170^{\Phi}$} \\
\hline $\begin{array}{l}\text { Drinker or } \\
\text { exdrinker }\end{array}$ & $582(75.9)$ & $78(67.8)$ & $30(76.9)$ & \\
\hline \multicolumn{5}{|l|}{ Overcrowding n (\%) } \\
\hline No & $477(62.2)$ & $90(78.3)$ & $25(64.1)$ & \multirow[t]{2}{*}{$0.004^{\Phi}$} \\
\hline Yes & $290(37.8)$ & $25(21.7)$ & $14(35.9)$ & \\
\hline
\end{tabular}

CG chronic gastritis, GU gastric ulcer, GC gastric cancer

$\Phi \mathrm{X}^{2}$ test $^{\delta}{ }^{\delta}$ Exact Fisher test

percent $(5 / 7)$ of patients with infection in tumor and surrounding tissue were positive for $b a b A 2+$.

We analyzed the combination and the frequency of the most virulent genotypes vacA/cagA/babA2. The vacA $s 1 m 1 / c a g A+/ b a b A 2+$ genotype was the most frequent in all groups, and its prevalence was higher in gastric cancer. The distribution of $v a c A / c a g A / b a b A 2$ genotypes was significantly different between groups $(p=0.041)$; data not shown. Of the patients with $H$. pylori in surrounding tissue and in tumor, 57.1\% (4/7) harbored the allele combination vacA s1m1/cagA+/babA2+, $14.3 \%(1 / 7)$ harbored the $s 2 m 2 / c a g A-/ b a b A 2-$ genotype and $14.3 \%$ $(1 / 7)$ the $s 2 m 2 / \operatorname{cag} A-/ b a b A 2+$ genotype.

\section{Association of $H$. pylori and $\operatorname{vacA}, \operatorname{cagA}$ and $b a b A 2$ genotypes with diagnosis}

Infection with $H$. pylori was associated with gastric cancer (adjusted OR 2.08; 95\% CI 1.05-4.13; $p=0.035$ ) but not with gastric ulcer (adjusted OR 1.07; 95\% CI 0.71$1.61 ; p=0.728$ ) (Table 4). A significant association was found between the $s 1 m 1$ genotype and ulcer and gastric cancer $\left(\mathrm{OR}_{\text {adjusted }}=2.02 ; 95 \%\right.$ CI 1.12-3.62; $p=0.019$ and $\mathrm{OR}_{\text {adjusted }}=6.58 ; 95 \%$ CI 2.15-20.08; $p=0.001$, respectively). The $b a b A 2$ gene was associated with gastric cancer $\left(\mathrm{OR}_{\text {adjusted }}=2.50 ; 95 \%\right.$ CI $\left.0.99-6.32 ; p=0.052\right)$; $\operatorname{cagA}$ was not associated with clinical outcome (Table 4).

\section{Discussion}

Helicobacter pylori is an important human pathogen associated with most cases of peptic ulcer disease, gastritis and gastric adenocarcinoma. In most people, infection with $H$. pylori is restricted to the gastric antrum, but in some patients the infection spreads both through the body and antrum [53].

There are few studies on the prevalence of $H$. pylori and of its $v a c A, \operatorname{cag} A$ and $b a b A 2$ genotypes in the Mexican population, and the data on the association of these genotypes with gastric diseases are still controversial in most countries. The clinical relevance and geographical distribution of the virulent genotypes of $H$. pylori is still a matter of debate. This study reports the prevalence and relationship of virulence genes ( $v a c A, \operatorname{cag} A$ and $b a b A 2)$ of $H$. pylori with clinical status in patients from South of Mexico.

The prevalence of $H$. pylori infection in chronic gastritis and gastric ulcer patients was $47.8 \%$ and $49.6 \%$, respectively, lower than that reported in other studies [6, $10,11]$. An important finding of this study was that seven (1\%) children aged 11-16 years had chronic gastritis and infection with $H$. pylori cagA+, and that a 19 -year-old was diagnosed with gastric ulcer and $H$. pylori vacA $s 1 m 1 / c a g A+/ b a b A 2+$. Gonzalez-Valencia et al. also reported that children from 2 to 16 years with abdominal pain were infected with $s 1$ or $s 2 / \operatorname{cag} A+$ genotypes. Infection with virulent genotypes of $H$. pylori at an early age may be related to the occurrence of gastric cancer before age 30 . In gastric cancer patients, the prevalence of $H$. pylori was $61.5 \%$, similar to that found in Mexican patients in a different geographical region (60\%) [9] and exceeding that reported by other authors (38\%) [44]. The differences in the prevalence of $H$. pylori in people from the same country may be due to the different number of biopsies analyzed for each patient, the variable number of bacteria harbored by the tissue studied, the difference in sensitivity and specificity of the PCR method used, the geographic region and the environmental health conditions of the population studied.

In gastric cancer patients, the frequency of $H$. pylori was higher in normal tissues adjacent to cancer (69.2\%) than in the tumor $(53.8 \%)$. Similar findings were made in Chinese patients [54] and in Mexican patients [44] 


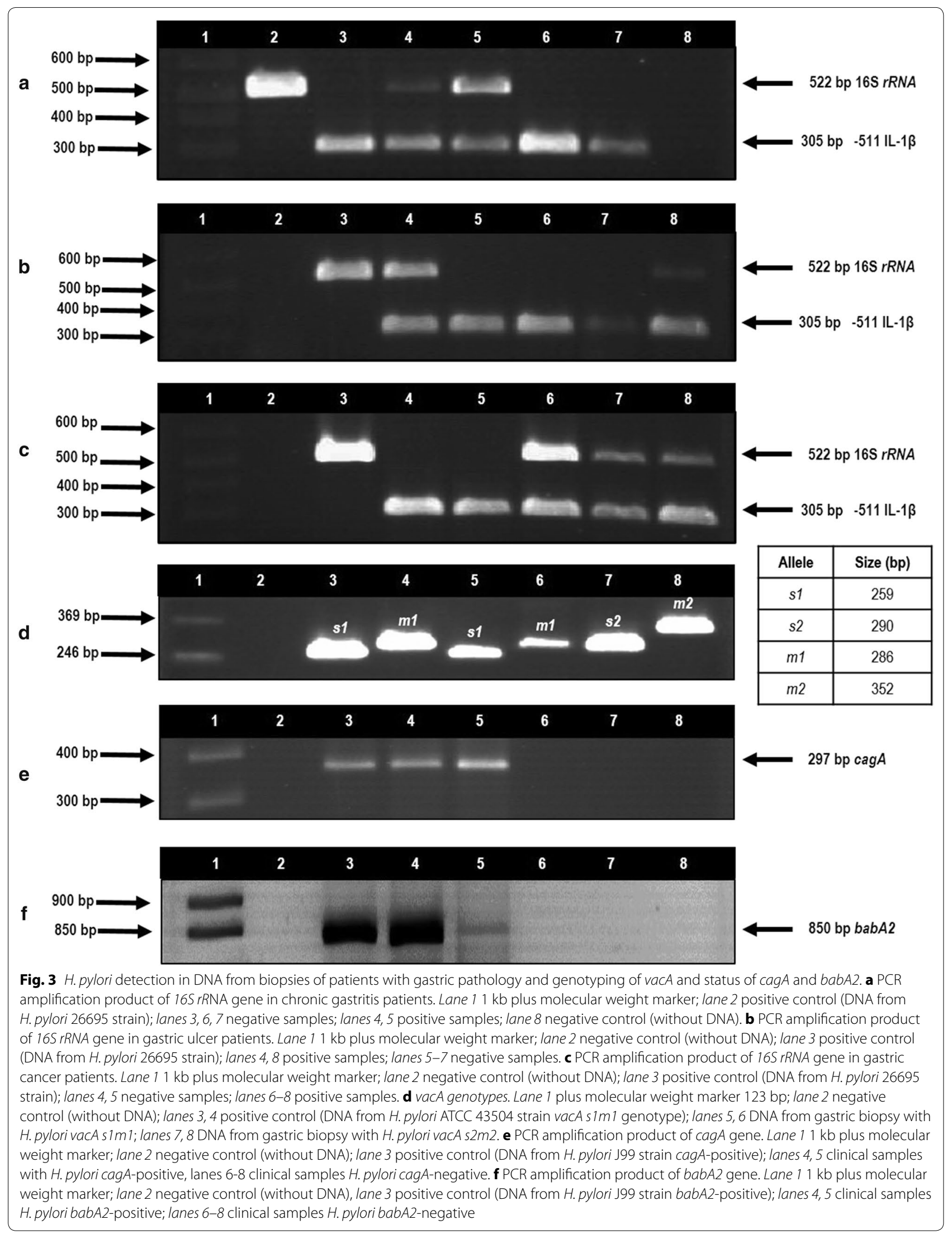


Table 2 H. pylori infection, status of cagA/babA2 and vacA genotypes in patients with gastric pathology

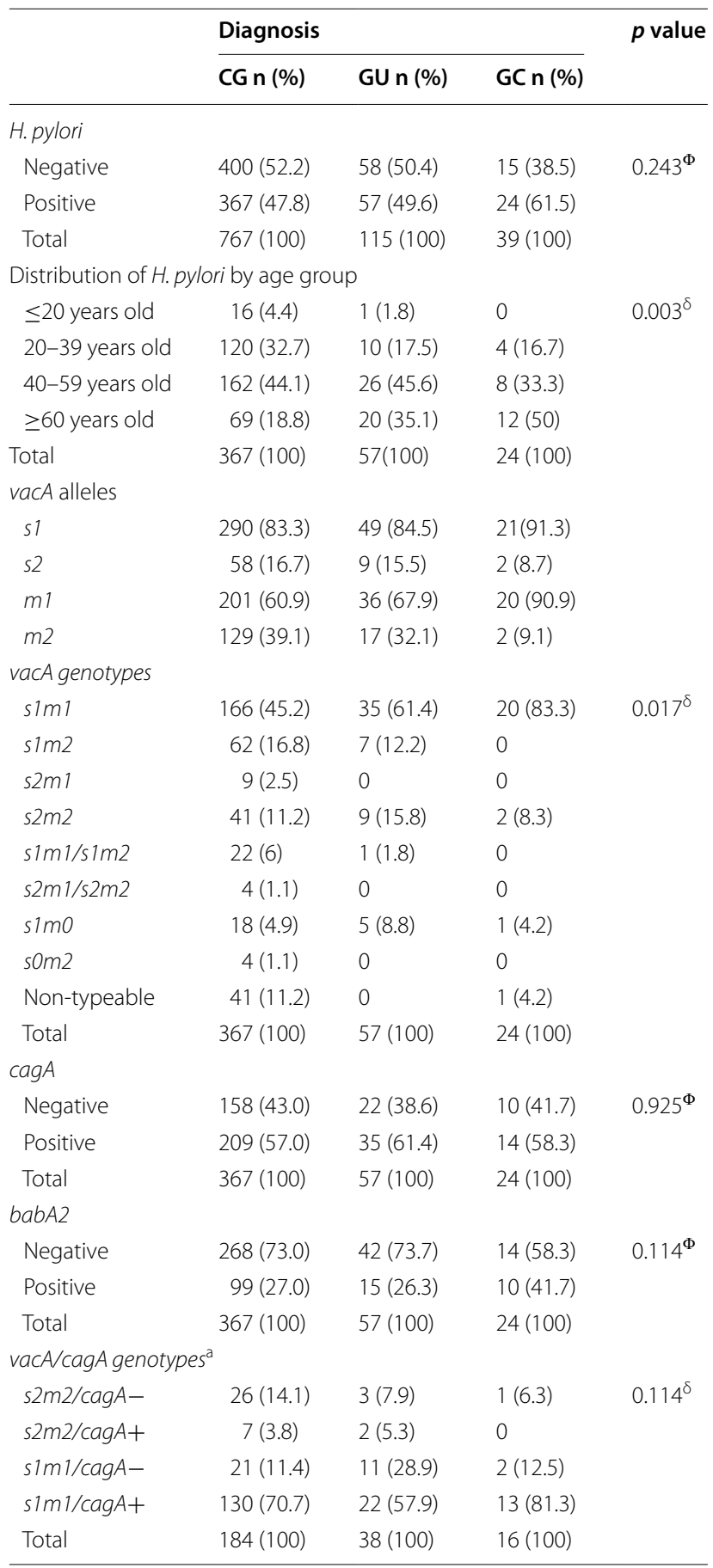

$C G$ chronic gastritis, GU gastric ulcer, GC gastric cancer

$\Phi \mathrm{X}^{2}$ test, ${ }^{\delta}$ Exact Fisher test; $\mathrm{s} 0$ : non-typeable for signal region. $\mathrm{m} 0$ : nontypeable for middle region

a In this analysis only were included the infections caused by one vacA genotype with gastric cancer. Although $H$. pylori can survive in the tumor, the microenvironment of cancerous epithelium and the changes experienced by cancer cells are detrimental to the survival of the bacteria [54]. Zhang et al, even proposed that the atrophic mucosa and intestinal metaplasia are detrimental to the growth of $H$. pylori, and Tang et al, mention that $H$. pylori plays an important role in early gastric carcinogenesis, but that it probably has less influence on later stages of the disease $[54,55]$. In this study, $H$. pylori is associated with gastric cancer but not with gastric ulcer.

Helicobacter pylori strains with the $s 1$ allele in the signal region of $v a c A$ were found in 83.3 and $84.5 \%$ of patients with chronic gastritis and gastric ulcer, respectively. The percentage increased to $91.3 \%$ in gastric cancer patients. With respect to the middle region, the $m 1$ allele was found in 60.9 and $67.9 \%$ of patients in the two groups without cancer, while $m 1$ strains were found in $90.9 \%$ of the patients with cancer. As has been demonstrated in other studies in the Mexican population $[6,10$, $42,43]$, the predominant allelic combination was $s 1 m 1$, followed by $s 1 m 2$ in patients with GC, GU and CG. Our results show that $60 \%$ of $H$. pylori-positive patients were infected with virulent $v a c A s 1 m 1$ strains, alone or in coinfection with the $\operatorname{sim} 2$ genotype. The $v a c A s 1 m 1$ genotype was associated with GU and GC. The VacA protein, a product of the $\operatorname{sim} 1$ combination, induces a more severe infiltration of neutrophils, and has higher vacuolating and apoptosis-inducing activity than the $s 2 m 2$ variant. In addition, VacA inhibits the expansion of the $\mathrm{T}$ cells activated by bacterial antigens and thus helps $H$. pylori evade the adaptive immune response and promotes the persistence of infection [53-55]. These properties of VacA may explain the association of the $s 1 \mathrm{~m} 1$ isoform with gastric ulcer and cancer. Interestingly, we found infection with $H$. pylori s $2 m 2$ in tumor and in tissue adjacent to cancer in two patients with gastric cancer; both strains were cagA-negative, but one was babA2-positive. Lopez-Vidal et al, also found the $s 2$ and $m 2$ alleles in Mexican patients with cancer [44]. This finding suggests that other virulence factors of $H$. pylori may be involved in cancer induction. It has been found that gastric cancer patients infected with Tip $\alpha+$ strains of $H$. pylori produce significantly higher amounts of TNF- $\alpha$ than patients with chronic gastritis, and that the TNF- $\alpha$-induced inflammatory response plays a significant role in the development of gastritis and gastric carcinoma associated with infection by $H$. pylori [56].

Although all strains of $H$. pylori contain the vacA gene, it was impossible to detect the $m$ and $s$ regions of 
Table 3 H. pylori and its virulence genes in tumor and adjacent tissue of patients with gastric cancer

\begin{tabular}{|c|c|c|c|c|c|c|c|c|c|c|}
\hline \multirow[t]{3}{*}{ Patient } & \multicolumn{5}{|c|}{ Adjacent tissue $n=13$} & \multicolumn{5}{|l|}{ Tumor $n=13$} \\
\hline & \multirow[t]{2}{*}{ rRNA 16S H. pylori } & \multicolumn{2}{|c|}{ vacA } & \multirow[t]{2}{*}{$\operatorname{cag} A$} & \multirow[t]{2}{*}{ babA2 } & \multirow[t]{2}{*}{ rRNA 165 H. pylori } & \multicolumn{2}{|c|}{ vacA } & \multirow[t]{2}{*}{$\operatorname{cag} A$} & \multirow[t]{2}{*}{$b a b A 2$} \\
\hline & & $s$ & $m$ & & & & $s$ & $m$ & & \\
\hline IEC02 & Negative & & & & & Negative & & & & \\
\hline IEC03 & Positive & s1 & $m 1$ & + & + & Positive & s1 & $m 1$ & + & + \\
\hline IEC04 & Negative & & & & & Negative & & & & \\
\hline IEC05 & Positive & s1 & m1 & + & - & Positive & s1 & $m 1$ & + & - \\
\hline IEC07 & Negative & & & & & Negative & & & & \\
\hline $\mathrm{IEC} 10$ & Positive & s1 & $m 1$ & - & - & Negative & - & - & - & - \\
\hline IEC11 & Positive & s2 & $m 2$ & - & + & Positive & s2 & $m 2$ & - & + \\
\hline $\mathrm{IEC} 12$ & Positive & s1 & $m 1$ & + & + & Negative & - & - & - & - \\
\hline IEC16 & Positive & s1 & $m 1$ & + & + & Positive & s1 & $m 1$ & + & + \\
\hline $\mathrm{IEC} 17$ & Positive & s1 & $m 1$ & + & + & Positive & s1 & $m 1$ & + & + \\
\hline IEC19 & Positive & s2 & $m 2$ & - & - & Positive & $s 2$ & $m 2$ & - & - \\
\hline IEC 20 & Negative & & & & & Negative & & & & \\
\hline IEC 21 & Positive & sl & $m 1$ & + & + & Positive & s1 & $m 1$ & + & + \\
\hline Total & 13 & 9 & 9 & 6 & 6 & 13 & 7 & 7 & 5 & 5 \\
\hline
\end{tabular}

The italic text refers to genes and alleles $s$ or $m$ of vacA of $H$. pylori

Table 4 Association of $H$. pylori and its virulence genes vacA s1m1, cagA, babA2 with gastric ulcer and gastric cancer

\begin{tabular}{|c|c|c|c|c|}
\hline & \multicolumn{4}{|l|}{ Diagnosis } \\
\hline & \multicolumn{2}{|l|}{ Gastric ulcer } & \multicolumn{2}{|l|}{ Gastric cancer } \\
\hline & OR (Cl 95\%) & $p$ value & $\mathrm{OR}^{\mathrm{a}}(\mathrm{Cl}$ 95\%) & $p$ value \\
\hline \multicolumn{5}{|l|}{ H.pylori } \\
\hline Negative & $1.0^{\mathrm{b}}$ & & $1.0^{b}$ & \\
\hline Positive & $1.07(0.71-1.61)$ & 0.728 & $2.08(1.05-4.13)$ & 0.035 \\
\hline \multicolumn{5}{|l|}{$\operatorname{vacA}$} \\
\hline$s 2 m 2$ & $1.0^{\mathrm{b}}$ & & $1.0^{\mathrm{b}}$ & \\
\hline $\operatorname{sim} 1$ & $2.02(1.12-3.62)$ & 0.019 & $6.58(2.15-20.08)$ & 0.001 \\
\hline \multicolumn{5}{|l|}{$\operatorname{cag} A$} \\
\hline Negative & $1.0^{\mathrm{b}}$ & & $1.0^{\mathrm{b}}$ & \\
\hline Positive & $1.02(0.56-1.86)$ & 0.934 & $1.22(0.47-3.17)$ & 0.676 \\
\hline \multicolumn{5}{|l|}{$b a b A 2$} \\
\hline Negative & $1.0^{\mathrm{b}}$ & & $1.0^{b}$ & \\
\hline Positive & $0.97(0.50-1.85)$ & 0.927 & $2.50(0.99-6.32)$ & 0.052 \\
\hline \multicolumn{5}{|l|}{ Genotype } \\
\hline$s 2 \mathrm{~m} 2 / \operatorname{cag} A-$ & $1.0^{\mathrm{b}}$ & & $1.0^{b}$ & \\
\hline$s 2 \mathrm{~m} 2 / \mathrm{cag} A+$ & $2.5(0.33-18.6)$ & 0.374 & - & - \\
\hline $\operatorname{siml} 1 / \mathrm{cag} A-$ & $4.3(1.02-18.2)$ & 0.047 & $1.8(0.15-22.1)$ & 0.639 \\
\hline $\operatorname{sim} 1 / \mathrm{cag} A+$ & $1.5(0.40-5.5)$ & 0.550 & $2.1(0.25-16.8)$ & 0.502 \\
\hline
\end{tabular}

\footnotetext{
a OR adjusted for age and overcrowding
}

b Reference group: chronic gastritis this gene in the genomic DNA of 42 of the 448 patients infected. Similar results have been reported in the Mexican population $[43,44]$. The genetic diversity of the $s$ and $m$ regions and the existence of undetectable $v a c A$ genes may explain the difficulty in genotyping some strains $[45$, 57, 58]. Moreover, H. pylori contain at least two copies of the $16 S$ and $23 S$ rRNA genes but only one of the $v a c A$ gene [59]. In some samples, the amplification signal of $16 S$ rRNA was almost undetectable (Fig. 3a, b); it is thus likely that the number of copies of the vacA gene was insufficient for detection by PCR.

The prevalence of cagA in this population was $57 \%$ in chronic gastritis patients, $61.4 \%$ in gastric ulcer patients and $58.3 \%$ in gastric cancer patients. This prevalence is lower than that reported in Central and South America $[15,19,60]$, but it is in agreement with previous studies in Mexico [10, 27]. The cagA-positive strains of $H$. pylori have been associated with a more severe inflammation of the gastric mucosa that precedes atrophic gastritis, peptic ulcer and gastric cancer [61-65]. In this research, cagA was not associated with gastric ulcer or cancer. This finding is in agreement with those reported by other authors in Mexican patients [45]. It is likely that gastric ulcer and cancer are associated only with the CagA isoforms that contain repetitions of the EPIYA-C motif. The type and number of EPIYA motifs in CagA was not determined in this research. 
Interestingly, cagA was found in $71.4 \%(5 / 7)$ of $H$. pylori-positive samples in tumor and surrounding tissue; the $s 1 m 1 / \operatorname{cag} A+\mid b a b A 2+$ genotype was found in $57.1 \%$ $(4 / 7)$ and the $s 1 m 1 / c a g A+/ b a b A 2-$ genotype in $14.3 \%$ $(1 / 7)$. This result is consistent with the activity of CagA to induce epithelial-mesenchymal transition and cell proliferation, inhibit apoptosis, promote the loss of tight junctions and carry out other functions related to tumor invasiveness and metastasis $[53,66]$. The presence of the $s 2 m 2 / c a g A-/ b a b A 2-$ and $s 2 m 2 / c a g A-/ b a b A 2+$ genotypes in tumor and surrounding tissue suggests that other bacterial compounds may be involved in the promotion of carcinogenesis and tumor maintenance.

The babA2 gene was found only in 27, 26.3 and $41.7 \%$ of chronic gastritis, gastric ulcer and cancer patients, respectively, and was marginally associated with gastric cancer $\left(\mathrm{OR}_{\text {adjusted }}=2.5,95 \%\right.$ CI $\left.0.99-6.32, p=0.052\right)$. The frequency of $b a b A 2$ in chronic gastritis patients was higher than that reported in Mexican patients [10], but lower than that reported for gastritis, gastric ulcer and cancer patients in other Central and South American countries $[19,20,67,68]$. Oliveira et al, also found an association of $b a b A 2$ with gastric cancer in patients from Brazil [20]. It is likely that the association of $b a b A 2$ with more severe gastric diseases that was found in this study is related to its coexistence with cagA and vacA s $1 \mathrm{~m} 1$ (59.7\%), as suggested by Chen et al. [69].

\section{Conclusions}

In conclusion, infection with $H$. pylori and related diseases occurred early in population of Southern Mexico. The prevalence of $H$. pylori was $47.8,49.6$ and $61.5 \%$ in chronic gastritis, gastric ulcer and cancer patients, respectively and the infection with this bacterium is associated with gastric cancer. The $s 1$ and $m 1$ alleles of $v a c A$ are predominant in this population, and the $s 1 m 1$ genotype is associated with gastric ulcer and cancer. The presence of the $s 2 \mathrm{~m} 2 / \mathrm{cagA}$-negative genotype in gastric cancer patients suggests that other virulence factors of $H$. pylori, or other infectious agents, may be involved in the carcinogenic process. Additionally, some host factors may be interacting with the virulence factors of $H$. pylori and they may play an important role in the gastric carcinogenesis. The prevalence of cagA in South Mexico is lower than that found in other countries of Central and South America, and cagA was not associated with gastric ulcer or cancer. The $s 1 m 1 / c a g A+/ b a b A 2+$ strains of H. pylori predominated in the tumor and in the surrounding tissue, and their presence may be related to the likelihood of invasion and metastasis.

\section{Authors' contributions}

GFT and MCP, ARR conceived and designed the study. JAM, JCAH, ASCC and RRR, carried out the molecular biology studies; DNMC participated in the design of the study and performed the statistical analysis; RBL, SRN and ICdC performed the endoscopic studies of patients and made substantial contributions to acquisition of data; CACS and EMCM reviewed critically the manuscript and contributed to analysis and interpretation of data; GFT, and ARR wrote the manuscript. All authors read and approved the final manuscript.

\section{Author details}

${ }^{1}$ Laboratorio de Investigación en Bacteriología, Facultad de Ciencias Químico Biológicas, Universidad Autónoma de Guerrero, Chilpancingo, Guerrero, México. ${ }^{2}$ Laboratorio de Investigación Clínica, Facultad de Ciencias Químico Biológicas, Universidad Autónoma de Guerrero, Avenida Lázaro Cárdenas S/N Ciudad Universitaria Sur, Col. La Haciendita, 39087 Chilpancingo, Guerrero, México. ${ }^{3}$ Hospital Regional de Alta Especialidad, Oaxaca, Oaxaca, México. ${ }^{4}$ Unidad Especializada en Gastroenterología Endoscopia, Chilpancingo, Guerrero, México. ${ }^{5}$ Servicio de Endoscopia, Instituto Estatal de Cancerología "Dr. Arturo Beltrán Ortega", Acapulco, Guerrero, México. ${ }^{6}$ Servicio de Endoscopia, Hospital General “Dr. Raymundo Abarca Alarcón”, Chilpancingo, Guerrero, México. ${ }^{7}$ Unidad de Investigación Médica en Enfermedades Infecciosas y Parasitarias, Hospital de Pediatría, Centro Médico Nacional Siglo XXI, IMSS, Ciudad de México, México. ${ }^{8}$ Laboratorio de Biología Molecular del Cáncer, Unidad de Investigación, Hospital Juárez de México, Ciudad de México, México.

\section{Acknowledgements}

We thank the nurses and staff who assisted in obtaining gastric biopsies. Special thanks to Martin O. Morrugares-Ixtepan, a specialist in Pathological Anatomy with a subspecialty in Pathological Oncology, who was responsible for the histopathological diagnosis of some of the samples. Our gratitude to the M.Sc. Monica Virginia Saavedra Herrera, Research Coordinator of the State Cancerology Institute "Arturo Beltran Ortega"; to the M.Sc. José Eduardo Navarro Zarza and to Dr. Engels Rodríguez, attached to the General Hospital Dr. Raymundo Abarca Alarcón, for their cooperation in the realization of this research.

\section{Competing interests}

The authors declare that they have no competing interests.

\section{Availability of data and materials}

Data sharing not applicable to this article as no datasets were generated or analyzed during the current study.

\section{Ethics approval, consent and permissions}

The project was approved by the Bioethics Committee of the Universidad Autónoma de Guerrero and by the Department of Teaching and Research of the General Hospital Dr. Raymundo Abarca Alarcón, Chilpancingo city and by the Research Department of the State Cancerology Institute, Acapulco, Guerrero.

The patients or their parents signed statements of informed consent. All procedures performed in studies involving human participants were in accordance with the ethical standards of the institutional and/or national research committee and with the 1964 Helsinki declaration and its later amendments or comparable ethical standards.

\section{Funding}

The research was conducted with funding from the Secretaría de Educación Pública of Mexico through PIFI 2006-2011 and the Support Program for Reintegration of Former Grantees PROMEP 2007 key PROMEP UAGUER-EXB-096. Part of the funding was obtained from the Universidad Autónoma de Guerrero (2010-2013 research grants) and from CONACYT through the support given to the Master program in Biomedical Sciences. During the study, Dinorah N. Martinez-Carrillo, Julio C. Azúcar-Heziquio, Abner S. Cuevas-Caballero and Roxana Reyes-Rios were fellows of CONACyT while doing their Masters in Biomedical Sciences. Adolfo Roman-Roman was awarded a scholarship by the Universidad Autónoma de Guerrero for doctoral studies.

\section{Publisher's Note}

Springer Nature remains neutral with regard to jurisdictional claims in published maps and institutional affiliations.

Received: 12 November 2016 Accepted: 5 April 2017

Published online: 13 April 2017 


\section{References}

1. Wroblewski LE, Peek RM Jr, Wilson KT. Helicobacter pylori and gastric cancer: factors that modulate disease risk. Clin Microbiol Rev. 2010;23:713-39.

2. Ishijima N, Suzuki M, Ashida H, Ichikawa Y, Kanegae Y, Saito I, et al. BabAmediated adherence is a potentiator of the Helicobacter pylori type IV secretion system activity. J Biol Chem. 2011;286(28):25256-64.

3. Azevedo NF, Guimarães N, Figueiredo C, Keevil CW, Vieira MJ. New mode for the transmission of Helicobacter pylori: role of environmental reservoirs as gene pools to increase train diversity. Crit Rev Microbiol. 2007;33:157-9.

4. Sahara S, Sugimoto M, Vilaichone RK, Mahachai V, Miyajima H, Furuta T, et al. Role of Helicobacter pylori cagA EPIYA motif and vacA genotypes for the development of gastrointestinal diseases in Southeast Asian countries: a meta-analysis. BMC Infect Dis. 2012;12:223.

5. Belkind-Gerson J, Basurto G. Incidencia de la infección por Helicobacter pylori en una cohorte de lactantes de Morelos. Salud Publ Mex. 2001;43:122-6.

6. Martínez-Carrillo DN, Garza-Gonzalez E, Bertancourt-Linares R, MónicoManzano T, Antúnez-Rivera C, Román-Román A, et al. Association of IL1B511C/-31T haplotype and Helicobacter pylori vacA genotypes with gastric ulcer and chronic gastritis. BMC Gastroenterol. 2010;10:126-32.

7. Fernández-Tilapa G, Axinecuilteco-Hilera J, Giono-Cerezo S, Martínez-Carrillo DN, Illades-Aguiar B, Román-Román A. vacA genotypes in oral cavity and Helicobacter pylori seropositivity among adults without dyspepsia. Med Oral Pathol Oral Cir Buccal. 2011;16:e175-80.

8. Cárdenas-Mondragón MG, Torres J, Flores-Luna L, Carreón-Talavera R, Camorlinga-Ponce M, Fuentes-Pananá EM. Epstein-Barr virus association with peptic ulcer disease. Anal Cell Pathol. 2015;2015:164840.

9. Morales-Espinosa R, Fernandez-Presas A, Gonzalez-Valencia G, FloresHernandez S, Delgado-Sapien G, Mendez-Sanchez JL, et al. Helicobacter pylori in the oral cavity is associated with gastroesophageal disease. Ora Microbiol Immunol. 2009;24:464-8.

10. Paniagua GL, Monroy E, Rodríguez R, Arroniz S, Rodríguez C, Cortés ال L, et al. Frequency of vacA, cagA and babA2 virulence markers in Helicobacter pylori strains isolated from Mexican patients with chronic gastritis. Ann Clin Microbiol Antimicrob. 2009;8:14.

11. Román-Román A, Giono-Cerezo S, Camorlinga-Ponce M, Martínez-Carrillo DN, Loaiza-Loeza S, Fernández-Tilapa G. vacA genotypes of Helicobacter pylori in the oral cavity and stomach of patients with chronic gastritis and gastric ulcer. Enferm Infecc Microbiol Clin. 2013;31(3):130-5.

12. Cárdenas-Mondragón MG, Torres J, Flores-Luna L, Camorlinga-Ponce M, Carreón-Talavera R, Gomez-Delgado A, et al. Case-control study of Epstein-Barr virus and Helicobacter pylori serology in Latin American patients with gastric disease. Br J Cancer. 2015;112(12):1866-73.

13. Con SA, Takeuchi H, Con-Chin GR, Con-Chin VG, Yasuda N, Con-Wong R. Role of bacterial and genetic factors in gastric cancer in Costa Rica. World J Gastroenterol. 2009;15(2):211-8.

14. Latifi-Navid S, Mohammadi S, Maleki P, Zahri S, Yazdanbod A, Siavoshi F, et al. Helicobacter pylori vacA d1/-i1 genotypes and geographic differentiation between high and low incidence areas of gastric cancer in Iran. Arch Iran Med. 2013:16(6):330-7.

15. Arévalo-Galvis A, Trespalacios-Rangel AA, Otero W, Mercado-Reyes MM, Poutou-Piñales RA. Prevalence of cagA, vacA, and iceA genes in $\mathrm{H}$. pylori strains isolated from Colombian patients with functional dispepsia. Pol Microbiol. 2012:61(1):33-40.

16. Gerhard M, Lehn N, Neumayer N, Borén T, Rad R, Schepp W, et al. Clinical relevance of the Helicobacter pylori gene for blood-group antigen-binding adhesin. Proc Natl Acad Sci USA. 1999;96:12778-83.

17. Acevedo M, Eriksson S, Mendes N, Serpa J, Figueiredo C, Resende LP, et al. Infection by Helicobacter pylori expressing the BabA adhesin is influenced by the secretor phenotype. J Pathol. 2008;215(3):308-16.

18. Chomvarin C, Namwat W, Chaicumpar K, Mairiang P, Sangchan A, Sripa $B$, et al. Prevalence of Helicobacter pylori vacA, cagA, cagE, iceA and babA2 genotypes in Thai dyspeptic patients. Int J Infect Dis. 2008;12(1):30-6.

19. Torres LE, Melián K, Moreno A, Alonso J, Sabatier CA, Hernández M, et al. Prevalence of vacA, cagA and babA2 genes in Cuban Helicobacter pylori isolates. World J Gastroenterol. 2009;15(2):204-10.

20. Oliveira AG, Santos A, Guerra JB, Rocha GA, Rocha AM, Oliveira CA et al. babA2- and cagA-positive Helicobacter pylori strains are associated with duodenal ulcer and gastric carcinoma in Brazil. J Clin Microbiol. 2003:41(8):3964-6.
21. Sgouras DN, Panayotopoulou EG, Papadakos K, Martinez-Gonzalez B, Roumbani A, Panayiotou J, et al. CagA and VacA polymorphisms do not correlate with severity of histopathological lesions in Helicobacter pyloriinfected Greek children. J Clin Microbiol. 2009;47(8):2426-34.

22. Acosta N, Quiroga A, Delgado P, Mercedes B, Jaramillo C. Helicobacter pylori CagA protein polymorphisms and their lack of association with pathogenesis. World J Gastroenterol. 2010;16(31):3936-43.

23. Woon AP, Tohidpour A, Alonso H, Saijo-Hamano Y, KwokT, Roujeinikova A Conformational analysis of isolated domains of Helicobacter pylori CagA. PLOS ONE. 2013;8(11):e7936.

24. Nogueira C, Figueiredo C, Carneiro F, Gomes AT, Barreira R, Figueira P, et al. Helicobacter pylori genotypes may determine gastric histopathology. Am J Parasitol. 2001;158:647-54.

25. Matteo MJ, Granados G, Peréz CV, Olmos M, Sanchez C, Catalano M. Helicobacter pylori cagA pathogenicity island genotype diversity the gastric niche of a single host. J Med Microbiol. 2007:56:664-9.

26. Nomura AM, Pérez-Pérez Gl, Lee J, Stemmermann G, Blaser MJ. Relation between Helicobacter pylori cagA status and risk of peptic ulcer disease. Am J Epidemiol. 2002;155(11):1054-9.

27. Torres J, Lopez L, Lazcano E, Camorlinga M, Flores L, Muñoz O. Trends in Helicobacter pylori infection and gastric cancer in Mexico. Cancer Epidemiol Biomark Prev. 2005;14:1874-7.

28. Murata-Kamiya N. Pathophysiological functions of the CagA oncoprotein during infection by Helicobacter pylori. Microbes Infect. 2011;13:799-807.

29. Hatakeyama M. Helicobacter pylori and gastric carcinogenesis. J Gastroenterol. 2009:44:239-48.

30. Miernyk K, Morris J, Bruden D, McMahon B, Hurlburt D, Sacco F, et al. Characterization of Helicobacter pylori cagA and vacA genotypes among Alaskans and their correlation with clinical disease. J Clin Microbiol. 2011:49(9):3114-21.

31. Rudi J, Kolb C, Maiwald M, Kuck D, Sieg A, Galle PR, et al. Diversity of Helicobacter pylori vacA and cagA genes and relationship to VacA and CagA protein expression, cytotoxin production, and associated diseases. J Clin Microbiol. 1998;36(4):944-8.

32. Gangwer KA, Shaffer CL, Suerbaum S, Lacy DB, Cover TL, Bordenstein SR. Molecular evolution of the Helicobacter pylori vacuolating toxin gene vacA. J Bacteriol. 2010;192(23):6126-35.

33. Marciorkowska E, Roszko I, Kowalczuk O, Kaczmarski M, Chyczewski L, Kemona A. The evaluation of vacA gene alleles frequency in Helicobacter pylori strains in adults in Podlaskies children and region. Folia Histochem Cytobiol. 2007:45(3):215-9.

34. Martins LC, Corvelo TC, Demachki S, Araujo MT, Assumpção MB, Vilar SC, et al. Clinical and pathological importance of vacA allele heterogeneity and cagA status in peptic ulcer disease in patients from North Brazil. Mem Inst Oswaldo Cruz. 2005;100(8):875-81.

35. Atherton JC, Cao P, Peek RM, Tummuru MKR, Blasser MJ, Cover TL. Mosaicism in vacuolating cytotoxin alleles of Helicobacter pylori. J Biol Chem. 1995:270:17771-7.

36. Blaser MJ, Atherton JC. Helicobacter pylori persistence: biology and disease. J Clin Invest. 2004:113(3):321-33.

37. Chang YH, Wang L, Lee MS, Cheng CW, Wu CY, Shiau MY. Genotypic characterization of Helicobacter pylori cagA and vacA from biopsy specimens of patients with gastroduodenal diseases. Mt Sinai J Med. 2006;73:622-6.

38. Kusters JG, van Vliet AH, Kuipers EJ. Pathogenesis of Helicobacter pylori infection. Clin Microbiol Rev. 2006:19(3):449-90.

39. Secretaría de Salud de México. Sistema Nacional de Vigilancia Epidemiológica. Sistema Único de Información. Panorama epidemiológico de las úlceras, gastritis y duodenitis en México, periodo 2003-2008 (primera de dos partes). Boletín de Epidemiología. 2010;27(18):1-47.

40. Abdo-Francis JM, Uscanga L, Sobrino-Cossio S, Rivera-Ramos JF, HuertaIga F, Tamayo de la Cuesta JL. Consenso Mexicano sobre Helicobacter pylori. Rev Gastroenterol Mex. 2007;72(3):323-38.

41. World Health Organization. International Agency for Research on Cancer. Globocan 2012: estimated cancer incidence, mortality and prevalence worldwide 2012. http://globocan.iarc.fr/. Accessed 06 Oct 2016.

42. Morales-Espinoza R, Castillo-Rojas G, Gonzalez-Valencia G, Ponce-de-León S, Cravioto A, Atherton CJ, et al. Colonization of Mexican patients by multiple Helicobacter pylori strains with different vacA and cagA genotypes. J Clin Microbiol. 1999;37:3001-4. 
43. Garza-González E, Bosques-Padilla FJ, Tijerina-Menchaca R, Pérez-Pérez $\mathrm{Gl}$. Characterization of Helicobacter pylori isolates from the north-eastern region of Mexico. Clin Microbiol Infect. 2004;10:41-5.

44. López-Vidal Y, Ponce-de-León S, Castillo-Rojas G, Barreto-Zuñiga R, TorreDelgadillo A. High diversity of vacA and cagA Helicobacter pylori genotypes in patients with and without gastric cancer. PLoS ONE. 2008;3(12):e3849.

45. González-Valencia G, Atherton JC, Muñoz O, Dehesa M, la Garza AM, Torres J. Helicobacter pylori vacA and cagA genotypes in Mexican adults and children. J Infect Dis. 2000;182(5):1450-4.

46. Stolte M, Meining A. The updated Sydney system: classification and grading of gastritis as the basis of diagnosis and treatment. Can J Gastroenterol. 2001;15(9):591-8.

47. Rugge M, Correa P, Dixon MF, Hattori T, Leandro G, Lewin K, et al. Gastric dysplasia: the Padova international classification. Am J Surg Pathol. 2000;24(2):167-76.

48. Sambrook J, Russel D. Molecular cloning a laboratory manual. New York: Cold Spring Harbor Laboratory Press; 2001.

49. Park CY, Kwak M, Gutierrez O, et al. Comparison of genotyping Helicobacter pylori directly from biopsy specimens and genotyping from bacterial cultures. J Clin Microbiol. 2003;41:3336-8.

50. Figura N, Vindigni C, Covacci A, Presenti L, Burroni D, Vernillo R, et al. cagA positive and negative Helicobacter pylori strains are simultaneously present in the stomach of most patients with non-ulcer dyspepsia: relevance to histological damage. Gut. 1998;42(6):772-8.

51. Argent RH, Zhang Y, Atherton JC. Simple method for determination of the number of Helicobacter pylori CagA variable-region EPIYA tyrosine phosphorylation motifs by PCR. J Clin Microbiol. 2005;43:791-5.

52. Salih BA, Bolek BK, Arikan S. DNA sequence analysis of cagA $3^{\prime}$ motifs of Helicobacter pylori strains from patients with peptic ulcer diseases. J Med Microbiol. 2010;59(Pt 2):144-8.

53. Polk DB, Peek RM. Helicobacter pylori: gastric cancer and beyond. Nat Rev Cancer. 2010;10:403-14.

54. Tang YL, Gan RL, Dong BH, Jiang RC, Tang RJ. Detection and location of Helicobacter pylori in human gastric carcinomas. World J Gastroenterol. 2005;11(9):1387-91.

55. Zhang C, Yamada N, Wu YL, Wen M, Matsuhisa T, Matsukura N. Comparison of Helicobacter pylori infection and gastric mucosal histological features of gastric ulcer patients with chronic gastritis patients. World J Gastroenterol. 2005;11(7):976-81.

56. Inoue K, Shiota S, Yamada K, Gotoh K, Suganuma M, Fujioka T, et al. Evaluation of a new tumor necrosis factor-a-inducing membrane protein of Helicobacter pylori as a prophylactic vaccine antigen. Helicobacter. 2009;14:135-43.

57. Wang J, Chi DS, Laffan JJ, Li C, Ferguson DA, Litchfield P, et al. Comparison of cytotoxin genotypes of Helicobacter pylori in stomach and saliva. Dig Dis Sci. 2002;47(8):1850-6.
58. Assumpção MB, Martins LC, Melo Barbosa HP, Barile KA, de Almeida SS, Assumpcão PP, et al. Helicobacter pylori in dental plaque and stomach of patients from Northern Brazil. World J Gastroenterol. 2010;16(24):3033-9.

59. Smith JG, Kong L, Abruzzo GK, Gill CJ, Flattery AM, Scott PM, et al. PCR detection of colonization by Helicobacter pylori in conventional, euthymic mice based on the 165 ribosomal gene sequence. Clin Diagn Lab Immunol. 1996;3(1):66-72.

60. Silva MR, Vinagre RM, Silva AV, Oliveira CS, Santos KN, Costa RA, et al. Differences in virulence markers between Helicobacter pylori strains from the Brazilian Amazon región. Rev Soc Bras Med Trop. 2013;46(3):358-61.

61. Figueiredo C, Van Doorn LJ, Nogueira C, Soares JM, Pinho C, Figueira P, et al. Helicobacter pylori genotypes are associated with clinical outcome in Portuguese patients and show a high prevalence of infections with multiple strains. Scand J Gastroenterol. 2001;36(2):128-35.

62. Blaser MJ, Perez-Perez GI, Kleanthous H, Cover TL, Peek RM, Chyou $\mathrm{PH}$, et al. Infection with Helicobacter pylori strains possessing cagA is associated with an increased risk of developing adenocarcinoma of the stomach. Cancer Res. 1995;55(10):2111-5.

63. Kuipers EJ, Perez-Perez GI, Meuwissen SG, Blaser MJ. Helicobacter pylori and atrophic gastritis. Importance of the cagA status. J Natl Cancer Inst. 1995;87(23):1777-80.

64. Wang SK, Zhu HF, He BS, Zhang ZY, Chen ZT, Wang ZZ, et al. CagA+ H. pylori infection is associated with polarization of Thelper cell immune responses in gastric carcinogenesis. World J Gastroenterol. 2007;13(21):2923-31.

65. Wang F, Meng W, Wang B, Qiao L. Helicobacter pylori-induce gastric inflammation and gastric cancer. Cancer Lett. 2014;345(2):196-202.

66. Yu H, Zeng J, Liang X, Wang W, Zhou Y, Sun Y, et al. Helicobacter pylori promotes epithelial-mesenchymal transition in gastric cancer by downregulating programmed cell death protein 4 (PDCD4). PLOS ONE. 2014;9(8):e105306.

67. Yamaoka Y, Souchek J, Odenbreit S, Haas R, Arngvist A, Borén T, et al. Discrimination between cases of duodenal ulcer and gastritis on the basis of putative virulence factors of Helicobacter pylori. J Clin Microbiol. 2002;40(6):2244-6.

68. Gatti LL, Módena JL, Payão SL, MdeA Smith, Fukuhara Y, Módena JL, et al. Prevalence of Helicobacter pylori cagA, iceA and babA2 alleles in Brazilian patients with upper gastrointestinal diseases. Acta Trop. 2006;100:232-40.

69. Chen MY, He CY, Meng X, Yuan Y. Association of Helicobacter pylori babA2 with peptic ulcer disease and gastric cancer. World J Gastroenterol. 2013;19(26):4242-51.

\section{Submit your next manuscript to BioMed Central and we will help you at every step:}

- We accept pre-submission inquiries

- Our selector tool helps you to find the most relevant journal

- We provide round the clock customer support

- Convenient online submission

- Thorough peer review

- Inclusion in PubMed and all major indexing services

- Maximum visibility for your research

Submit your manuscript at www.biomedcentral.com/submit 